8. Программы для 1 и 2 ступени семилетней единой трудовой школы. - Москва : ГИЗ, 1921 356 с. 9. Програмні матеріали для 2-го концентру трудових шкіл. - Харків : Народний учитель, 1929. - 278 с.

Аліна Волощук

\title{
СТАНОВЛЕННЯ ХУДОЖНЬОЇ ОСВІТИ НА ЗАКАРПАТТІ В ПЕРШЙ ПОЛОВИНІ ХХ СТОЛІТТЯ
}

Волощук А. В. Становлення художньої освіти на Закарпатті в першій половині ХХ століття.

У статті розкриваються етапи становлення художньої освіти на Закарпатті в першій половині XX століття. Акцентовано увагу на тому, що педагогічна діяльність і плідна творчість професійних художників А. Ерделі та Й.Бокшая надали потужного імпульсу створенню закарпатської школи живопису.

Ключові слова: художня освіта, образотворче мистецтво, закарпатська школа живопису, естетичне виховання, художня школа.

Волощук А. В. Становление художественного образования на Закарпатье в первой половине XX столетия.

В статье раскрываются этапы становления художественного образования на Закарпатье в первой половине XX века. Акцентировано внимание на том, что педагогическая деятельность и плодотворное творчество профессиональных художников А. Ердели и Й. Бокшая дали мощный импульс для создания закарпатской школы живописи.

Ключевые слова: художественное образование, изобразительное искусство, закарпатская школа живописи, эстетическое воспитание, художественная школа.

Voloshchuk A. V. Formation of artistic education in Transcarpathia in the first half of the $20^{\text {th }}$ century.

The stages of artistic education development in Transcarpathia in the first half of the $20^{\text {th }}$ century are revealed. It is emphasized that pedagogical activity and oeuvre of such professional artists as A. Erdely and J. Bokshai gave powerful impulse to creation of Transcarpathian painting school.

Key words: artistic education, fine art, painting school of Transcarpathia, aesthetic education, school of art.

Нині проблема вивчення історії становлення художньої освіти на Закарпатті, а також ролі видатних діячів освіти і мистецтва в цьому процесі $\epsilon$ актуальною, оскільки цілеспрямоване проникнення в логіку та структуру розвитку художньої освіти на Закарпатті не лише поглиблює розуміння еволюції цього процесу у ХX столітті, а й допомагає усвідомити їі місце, закономірності, тенденції розвитку в загальноукраїнському вимірі.

Образотворчі надбання Закарпаття початку XX століття досліджувалися науковцями В. Бадяком, Л. Владичем, С. Жупанином, В. Курильцевою, В. Мартиненком, І. Небесником, Г. Островським.

Mema cmammi полягає у спробі простежити основні віхи становлення закарпатської школи живопису, проаналізувати роль художників-педагогів у формуванні мистецького 
середовища, активізації інтересу до образотворчого мистецтва серед широкого загалу.

Становлення художньої освіти на Закарпатті на початку XX ст. відбувалося в непростих політичних i соціально-економічних умовах. Унаслідок політики АвстроУгорщини, у складі якої перебувало Закарпаття (Угорська Русь), освіта перебувала в занедбаному стані, здобуття будь-якої кваліфікованої художньої спеціальності було неможливим, а брак професійних навичок уповільнював розвиток мистецтва краю [6, с. 27]. Неможливість самореалізації митця у власному національному середовищі спрямовувала молодь на здобуття художньої освіти в європейські центри - Париж, Відень, Мюнхен. Повернувшись додому дипломованими фахівцями, вони сприяли піднесенню національної культури своєю діяльністю. Образотворче мистецтво Закарпаття початку ХХ ст. презентували художники Ф. Видра, Й. Змій-Микловшик, К. Ізай, Д. Іяс, I. Ревес, Ф. Хевердле, однак через відсутність механізму передавання знань молоді, суттєвого впливу на розвиток мистецької школи не мали.

Художником, чия творчість вплинула на становлення образотворчого мистецтва Закарпаття, а живописна манера була підтримана молодими художниками Німеччини, Франції, Угорщини, став представник угорського та європейського демократичного реалістичного напряму М. Мункачі. Його послідовником і учнем уважається угорський живописець, професор Будапештської академії мистецтв І. Ревес, що проживав у м. Севлюш (Виноградово, Закарпаття).

На вдосконалення професійної майстерності закарпатських художників вплинула діяльність знаменитої приватної художньої школи-студії під керівництвом угорця Ш. Голлоші в Мюнхені. Методика навчання рисунку в цьому мистецькому осередку грунтувалася на академічних знаннях, реалістичному малюванні. Досвід керівництва мюнхенською живописною студією дав можливість Ш. Голлоші заснувати в м. Надьбаня (1896), неподалік від Закарпаття, літню художню колонію на природі, що стало визначною подією для образотворчого мистецтва Угорщини, сприяло формуванню національної художньої школи. Навколо неї згуртувалася обдарована молодь - угорці, росіяни, українці, грузини, поляки, чехи, серби, німці, французи. Згодом Ш. Голлоші переводить свою школу 3 майстернею в м. Тячів на Закарпаття (1904). Педагогічна діяльність митця вивела на мистецьку стежину багатьох художників, серед яких - I. Білібін, Д. Богословський, М. Верьовкіна, М. Добужинський, В. Кандінський, Д. Кардовський, О. Мурашко, А. Явлінський, а також вихідці 3 Закарпаття - Д. Віраг, І. Грабар, О. Грабовський, І. Грюнвальд, І. Реті, Я. Торма, К. Ференці та інші. Роль Ш. Голлоші в історії художньої освіти Закарпаття надзвичайно важлива, однак, грунт для закріплення його напрацювань був ще достатньо слабким. Учнем Ш. Голлоші був закарпатський художник-портретист, майстер церковного розпису Д. Віраг, який у подальшому отримав мистецьку освіту у школі зразкового рисунку професора Балло в Будапешті, продовжив у Мюнхенській академії, в академії Жюльєна в Парижі, вдосконалювався в живописних і рисункових класах Iталії, Іспанії, Америки. Однак, засвоєні професійні знання та навички академічного рисунку він не зміг передати молодому поколінню митців [7, с. 117].

Нові умови для розвитку Підкарпатської Русі виникли у зв’язку з входженням краю до складу Чехословацької республіки (вересень 1919), що спричинило позитивні зміни в освітньо-культурному та мистецькому житті. Розвитку художніх талантів краю сприяли навчальні заклади - Ужгородська півчо-учительська семінарія (керована засновником української національної школи на Закарпатті А. Волошиним (у 1939 - Президент незалежної Карпатської України) та Ужгородська реальна гімназія (під директоруванням 
А. Алиськевича), які спрямували навчально-виховну роботу на естетичне виховання учнів засобами музики, хорового співу, театрального та образотворчого мистецтва. Августин Волошин уважав одним із головних завдань школи розвиток уміння учнів висловлювати свої ідеї, думки, настрої, почуття малюнком та ручними виробами. Розуміючи, що успіхи вихованців в опануванні основ образотворчого мистецтва багато в чому залежать від особистості і професіоналізму вчителя, дирекція обох закладів запросила на посаду викладача малювання, креслення та дескриптивної геометрії професійних художників із академічною освітою - випускників Мукачівської гімназії та Будапештської академії мистецтв - Адальберта Ерделі (в Ужгородську семінарію) та Йосипа Бокшая (в Ужгородську гімназію). Педагогічна діяльність і плідна творчість цих митців надала суттєвого імпульсу розвитку художній освіті на Закарпатті власне для українського населення, що згодом, спричинило появу особливого мистецького явища - закарпатської школи живопису.

А. Ерделі здобув освіту в Мукачівській гімназії, вчительській семінарії міста Мараморош Сігот (сучасна Румунія), у Будапештському угорському королівському художньому інституті, де його вчителями з фаху були відомі талановиті художники А. ІваніГрюнвальд, Ф. Ольдяї, І. Ревес. Отримавши диплом професійного художника та вчителя малювання з відзнакою, А. Ерделі вдосконалюється в майстернях Т. Земплені, К. Ференці в Кечкеметській художній колонії. Педагогічна діяльність розпочалася одночасно в кількох закладах (1916 - 1922): горожанській школі, гімназії та семінарії м. Мукачева. Але творче покликання було домінуючим, тому А. Ерделі слідом за земляками Д. Вірагом, Ш. Голоші, Г. Рошковичем здійснює подорож «у вир мистецького життя» до Мюнхена (1922 - 1925). Під опікою художника Франке А. Ерделі виконує велику кількість портретів відомих людей Мюнхена, знайомиться $з$ шедеврами мюнхенської Пінакотеки і Дрезденської галереї, бере активну участь в об'єднанні баварських художників, експонується у кращих виставкових залах. Повернувшись в Ужгород (1925), А. Ерделі продовжує педагогічну діяльність в Ужгородській учительській семінарії. Згодом митець знову їде у Францію (1929), уважаючи, що світова культура твориться в Парижі, де працюють Пікассо, Матіс, Леже, Марке. У художній колонії Гаржилес він ознайомлюється 3 ідеями і принципами європейського експресіонізму, а вагомими результатами стають багаточисельні персональні виставки майже в усіх столицях Європи [3].

Його товариш - Й. Бокшай середню освіту здобув у Мукачівській гімназії, професійну - в Будапештській академії мистецтв на педагогічному відділенні, де викладачем спеціальних дисциплін був угорський живописець I. Ревес. Педагогічна діяльність Й. Бокшая розпочалася в Ужгородській горожанській школі, а $з 1919-1945$ р. продовжилася в Ужгородській реальній гімназії. Творча праця художника поєднувалася 3 громадською діяльністю, яка полягала в активній участі в Руській народній раді (1918-1919), «Просвіті» (1920). 3 метою вдосконалення майстерності, митець здійснює поїздки до Італії, Німеччини, Франції, Югославії.

А. Ерделі та Й. Бокшай зініціювали проведення в Мукачеві, Берегові та Кошицях першої спільної виставки творів закарпатських і словацьких художників (1921), серед яких виділялися Д. Віраг, Е. Грабовський, К. Ізай, Д. Іяс, Т. Муссон. Після виставкової діяльності формується «Клуб художників Підкарпатської Русі», члени якого розпочинають регулярний показ своїх творів, стимулюючи культурне піднесення краю.

Педагогічні зусилля А. Ерделі та Й. Бокшая націлювалися, перш за все, на виховання талановитої молоді, яка виявлялася в стінах Ужгородської реальної гімназії та Ужгородської вчительської семінарії. Однак, на думку викладачів, семінарія та гімназія недостатньо 
формували професійних художників, тому поставало питання про створення спеціалізованого художнього навчального закладу з широкою палітрою фахових дисциплін. А. Ерделі та Й. Бокшай частково реалізували ці наміри з відкриттям приватної суботньонедільної публічної художньої школи в Ужгороді (1927), яка в більшому обсязі надавала талановитим учням грунтовні знання з рисунку, живопису, композиції, історії мистецтв, які вивчалися згідно з програмами академічних художніх навчальних закладів. Саме Публічна школа малювання стала фундаментом художньої освіти Закарпаття, надала можливість систематично впливати на молоде покоління. Педагогічну діяльність А. Ерделі та Й. Бокшай поєднують із творчою, про що свідчать виставки в Ужгороді, Познані, Брно (1928), персональна виставка А. Ерделі у Празі та Ужгороді (1929).

Друга половина 20-х - початок 30-х pp. ХХ ст. для розвитку художньої освіти Закарпаття $є$ особливо важливим періодом, оскільки педагогами-митцями з числа студентів семінарії та гімназії, учнів Публічної художньої школи було підготовлено перше покоління художників. На мистецьку стежину вийшли майбутні корифеї українського образотворчого мистецтва - А. Борецький, В. Габда, Ю. Герц, В. Дван-Шарпотокі, А. Добош, А. Кашшай, Е. Контратович, А. Коцка, З. Шолтес, І. Шутєв та ін. Значна частина вихованців продовжила навчання у вищих художніх закладах Праги, Брно і Братислави - I. Гарапко, В. Свида, В. Касіян, Ф. Манайло, а повернувшись на батьківщину, продовжували традиції своїх учителів на педагогічній ниві в різних населених пунктах Закарпаття.

У зв'язку з кількісним та якісним зростанням мистецьких сил у краї А.Ерделі та Й. Бокшай організовують «Товариство діячів образотворчого мистецтва Підкарпатської Русі» (1931), яке згуртовує митців - представників різних національностей: М. БенешовуШпалову, Е. Дьордя, Л. Кайгла, Б. Ождіяна, Й. Томашека, Я. Цупала, А. Борецького, В. Дван-Шарпотокі, А. Добоша, Е. Контратовича, А. Коцку, 3. Шолтеса та ін. [2, с. 434]. Товариство обгрунтувало принципи, яких повинні дотримуватися молоді художники задля досягнення помітних успіхів, серед яких: висока загальнофахова академічна підготовка, глибоке осмислення народного мистецтва, вивчення досягнень і напрямів розвитку світового мистецтва.

Угорський період в історії краю (1939-1944) уповільнив розвиток національної культури, мистецької школи, виховання нового покоління митців. Однак, навіть в цей час, Й. Бокшай разом із А. Ерделі створюють нове об’єднання - «Союз підкарпатських художників» (1940), яке ініціює виставки, що з 1942 р. стали традиційними і налічували 5-6 вернісажів протягом року [5].

В атмосфері воєнного часу художники намагаються зберегти творче спілкування й відродити «Підкарпатський Барбізон», збираючись на пленери в с. Ставне Великоберезнянського району та с. Кушниця Іршавського району. Така форма співпраці підтримувала потенціал сформованих майстрів пензля, але не вирішувала питання виховання наступних поколінь митців. Навчальні заклади, де працювали А. Борецький, А. Добош, Е. Контратович, А. Коцка, Ф. Манайло, сприяли розкриттю обдарованості молоді, однак виведенню їх на творчий шлях мистецтва заважали політичні обставини [4].

Новий період розвитку художньої освіти Закарпаття започатковано в повоєнний час, коли край увійшов до складу Радянської України (1945). У червні того ж року в Ужгороді перебували представники Ради народних комісарів УРСР - М. Бажан та П. Тичина, які відвідали майстерні Й. Бокшая, А. Ерделі, А. Коцки, Ф. Манайла. Перед гостями з Києва ужгородські митці порушили питання про відкриття художнього навчального закладу для стабільного розвитку української художньої культури. У серпні 1945 р. на Закарпаття 
приїхала представницька делегація діячів культури у складі А. Бучми, П. Панча, А. Штогаренка, Г. Юри, художників М. Глущенка та В. Касіяна, яка повинна була обговорити питання щодо формування обласних відділень творчих спілок України, налагодження зв'язків між українськими митцями, створення художнього училища та дитячих художніх шкіл на Закарпатті. Як результат, розпочала свою роботу Закарпатська організація Спілки художників України (серпень 1946), яку очолив А. Ерделі. Талановиті митці презентували себе на VIII Українській художній виставці в Києві, в Ужгороді, Кошицях, Мукачеві, Празі, Братиславі [5]. Художня школа Закарпаття стала відомою в мистецьких колах Києва, Львова, Москви, що забезпечило налагодження тісних зв'язків із творчою елітою - К. Белашовою, М. Глущенком, І. Грабарем, В. Касіяном, С. Шишко, Т. Яблонською, мистецтвознавцями Г. Островським, Ю. Рейнером, В. Цельтнером.

Одночасно зі спілчанською діяльністю А. Ерделі та Й. Бокшай продовжували взаємодію з обласними та республіканськими представниками влади щодо відкриття художнього навчального закладу в Ужгороді. У 1946 р. проходила нарада активу працівників освіти Закарпаття, у роботі якої брали участь державні діячі М. Хрущов, П. Тичина, Г. Пінчук, професори С. Чавдаров та Г. Костюк. Одним із питань порядку денного був перехід навчальних закладів Закарпатської області на навчальні плани і програми, які діяли в УРСР. Тому було прийняте рішення відкрити 31 березня 1946 р. Ужгородське державне художньо-промислове училище для забезпечення подальшого розвитку художньої освіти Закарпаття [1, с. 491]. Першим директором училища було призначено А. Ерделі, фахове викладання забезпечували Й. Бокшай, В. Берец, А. Борецький, І. Гарапко, Е. Контратович, А. Коцка, Ф. Манайло, Ш. Петкі, В. Свида та інші.

Визнання прийшло і до Й. Бокшая: нагороджений орденом «Знак Пошани» (1948), став Заслуженим діячем мистецтв УРСР (1951), членом-кореспондентом Академії мистецтв СРСР (1958), Народним художником УРСР (1960), Народним художником СРСР (1963).

Випускники Ужгородського училища прикладного мистецтва повоєнних років поповнили лави видатних художників і склали кістяк Закарпатської обласної організації Спілки художників УРСР - це Й. Бабинець, Л. Балла, П. Балла, І. Барнич, Й. Бачинський, П. Бедзир, М. Белень, Й. Бокшай (молодший), І. Бровді, Л. Бровді, В.Бурч, В. Габда, Л. Гайду, І. Гарапко, Н. Герц, Ю. Герц, Г. Горват, Т. Данилич, А. Дунчак, В. Звенигородський, М. Іванчо, І. Ілько, А. Кашшай, Е. Контратович, Б. Корж, Є. Кремницька, Б. Кузьма, С. Мальчицький, Е. Медвецька, М. Медвецький, В. Микита, М. Микуляк, М. Михайлик, З. Мичка, Й. Пал, І. Палаташ, Н. Пономаренко, В. Приходько, М. Пуглик, М. Романишин, Й. Рущак, О. Саллер, М. Санич, М. Сапатюк, В. Свалявчик, В. Свида, Ф. Семан, В. Скакандій, Ю. Сташко, С. Усик, А. Шепа, З. Шолтес, І. Шутєв, В. Щур та інші.

Освітньо-художні процеси на Закарпатті в поєднанні з усталеною європейською традицією, надали можливість виокремити місцеві етнічні вияви, які поступово сформували національний стиль образотворчого мистецтва, а згодом своєрідну закарпатську школу живопису. Педагогічна діяльність і плідна творчість А. Ерделі та Й. Бокшая надали потужного імпульсу зміцненню мистецтва Закарпаття, сприяли становленню професійної художньої освіти, закарпатської школи живопису, яка стала визначним явищем у культурному житті України.

\section{Література}

1. Нариси історії Закарпаття (1946 - 1991) : [у 3 т.]. - Ужгород : Госпрозрахунк. РВВ упр. у справах преси та інформації, 2003. - Т. III. - 2003. - 648 с. 2. Нариси історії Закарпаття 
(з найдавніших часів до 1918 року) : [у 3 т.]. - Ужгород : Госпрозрахунк. РВВ Закарпат. облас. упр. по пресі, 1993. - Т. І. - 1993. - 436 с. 3. Небесник I. I. Адальберт Ерделі : [монографія] / Іван Іванович Небесник. - Львів : Мс., 2007. - 296 с. 4. Небесник I. I. Художня освіта Закарпаття в контексті розвитку художньої освіти в Україні (1945 - 1999 pp.) : [монографія] / I. І. Небесник. - Ужгород: Закарпаття, 2000. - 161 с. 5. Небесник I. I. Художня освіта на Закарпатті у XX столітті : історико-педагогічний аспект : [монографія] / I. I. Небесник; Львівська академія мистецтв. - Ужгород : Закарпаття, 2000. - 165 с. 6. Островський Г. С. Образотворче мистецтво Закарпаття / Григорій Семенович Островський. - Київ : Мистецтво, 1974. - 200 с. 7. Поп И. Энциклопедия Подкарпатской Руси / И. Поп; Карпато-русский Этнологический Исследовательский Центр США. - Ужгород : Изд-во В. Падяка, 2001. - 432 с.

УДК 378

Віма Гаманюк

\section{ІНШОМОВНА ПІДГОТОВКА У ШКОЛАХ ФРН : НАЦІОНАЛЬНІ ТРАДИЦІЇ ТА ЗАГАЛЬНОСВРОПЕЙСЬКІ ТЕНДЕНЦЇ̈}

Гаманюк В. А. Іншомовна підготовка у школах ФРН : національні традиції та загальноєвропейські тенденції.

У статті порушуються питання впливу мовної політики на організацію та зміст навчання іноземних мов у системі шкільної освіти у ФРН. Досліджуються підходи до навчання іноземних мов 3 огляду на мультикультурний характер суспільства та певну автономію федеральних земель у розв'язанні освітніх питань. Вказується на проблемні місця в розв'язанні питань іншомовної підготовки й дискусійні питання в науковому просторі ФРН, які торкаються організації навчання іноземних мов.

Ключові слова: мовна пропозиція, мовна політика, диверсифікація мов, багатомовність, навчання іноземних мов.

Гаманюк В. А. Иноязычная подготовка в школах ФРГ: национальные традиции и общеевропейские тенденции.

В статье поднимаются вопросы влияния языковой политики на организацию и содержание обучения иностранным языкам в системе школьного образования ФРГ. Исследуются подходы к обучению иностранным языкам с учетом мультилингвального характера общества и определенной автономии федеральных земель в решении вопросов образования. Указывается на проблемные места в решении вопросов иноязычной подготовки и на дискуссионные в научных кругах ФРГ вопросы, которые касаются организации обучения иностранным языкам.

Ключевые слова: языковое предложение, языковая политика, диверсификация языков, многоязычие, обучение иностранным языкам.

Hamanyuk V. A. Foreign language training schools in Germany: national traditions and European trends.

The article raised the impact of language policy on the organization and content of teaching foreign languages in the school system in Germany. We investigate approaches to teaching foreign languages in view of multilingual nature of society with certain autonomy of the federal states in solving educational issues. Problem areas in matters of foreign language training as well as debating 